\title{
SiM
}

\section{Following the Footsteps of the Mongol Queens: Why Mongolian Pastoral Women Should Be Empowered}

\author{
By Tungalag Ulambayar and María E. Fernández-Giménez
}

\section{On the Ground}

- Mongolian pastoral women have essential roles as caregivers to their families, keeping their household members well fed, adequately dressed, and clean. However, when they are forced to lead their households alone, female-led families are more vulnerable because of limited assets and restricted access to information and knowledge exchange.

- When women are entrusted with leadership of their communities, they demonstrate equal leadership qualities, reputation, and governance processes over rangeland management with their male counterparts.

- Women leaders display superior trust building among their community members when compared with the men.

- We recommend empowering women by increasing their leadership roles in formal community organizations.

Keywords: pastoral women, female-led households, women leadership, gender in range management.

Tras los pasos de las reinas mongolas: ¿por qué deben ser empoderadas las pastoras mongolas?

\section{Perspectiva desde el campo:}

- Las pastoras mongolas desempeñan papeles indispensables como encargadas del cuidado de sus familias y de mantener bien alimentados, debidamente vestidos y aseados a los miembros de sus unidades domésticas. Sin embargo, cuando son forzadas a dirigir sus hogares por sí solas, las familias encabezadas por mujeres son más vulnerables debido a los limitados recursos y el acceso restringido al intercambio de información y conocimientos.

- Cuando a las mujeres se les encomienda el liderazgo de sus comunidades, ellas demuestran iguales calidades de liderazgo, prestigio y procesos de gobernabilidad sobre la gestión de los pastizales y tierras silvestres que sus contrapartes masculinos.

- Las mujeres líderes muestran una construcción de confianza más alta entre los miembros de su comunidad en comparación con los hombres.

- Recomendamos empoderar a las mujeres al incrementar sus roles de liderazgo en las organizaciones comunitarias formales.

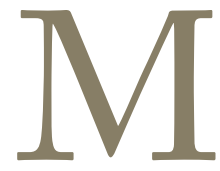
ongolia is the native country of Genghis Khan, who once ruled a vast empire of the steppes that shaped much of the modern world. ${ }^{1}$ Located between Russia and China, today's Mongolia is a developing country in a geopolitically sensitive region. The country possesses a large territory of more than 1.5 million $\mathrm{km}^{2}$ Most of Mongolia's land area is rangeland, from the Gobi desert in the south, to the forested and mountainous steppes of the north. With its 2.8 million people, Mongolia is the most sparsely populated country in the world. ${ }^{2}$ Besides its unique history of nomadism, the country is famous for abundant dinosaur fossils discovered by Roy Chapman Andrews, the American explorer. More recently, Mongolia has become a center of global mining 


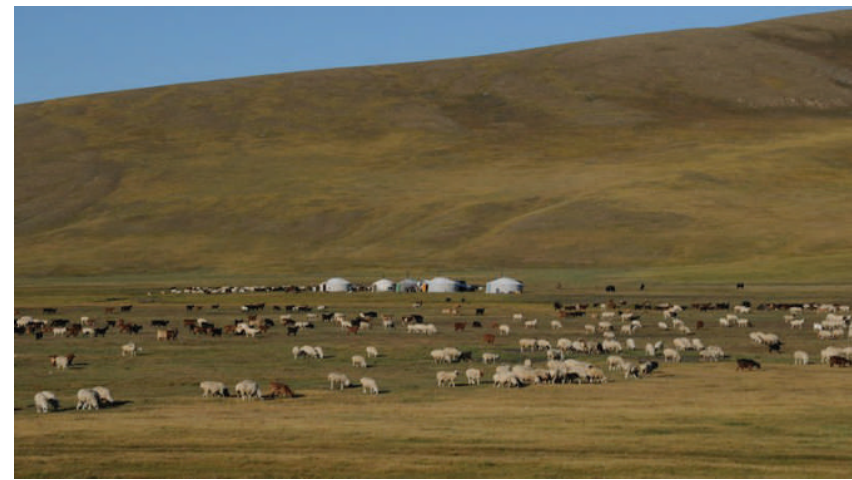

Figure 1. Rural landscape in Mongolia: gers (traditional dwelling of pastoralists) and grazing animals. Photo courtesy of Sabine M. Schmidt.

activity because of its large, newly discovered mineral deposits. In the early 1990s, after 70 years of communist rule, Mongolia became a democratic society, replacing the former centrally planned economy with a free market system (see Fig. 1).

Historically, Mongolian women were legendary in the world arena. Anthropologist Jack Weatherford wrote of them, "When they could, they raised their children in peace, but when it was necessary, they put on the helmet of war, took up the bows and arrows of battle, and went forth to defend their nation and their families. The royal Mongol women raced horses, commanded in war, presided as judges over criminal cases, ruled vast territories, and sometimes wrestled men in public sporting competitions." ${ }^{3}$ This remarkable background leads to the question, how do their descendants fare today?

Mongolian women gained the right to vote in 1924, preceding many developed nations of the time. The 2012 Global Gender Gap report produced by the World Economic Forum ranked Mongolia first for gender equality in the categories of "economic participation and opportunity" as well as "health and survival." 4 In contrast, the country ranked 127th among 135 nations in terms of women's political participation, indicating male-dominated decisionmaking in Mongolia. Women in Mongolia account for $51.4 \%$ of the total population and $45.7 \%$ of the country's workforce. Forty-two percent of those employed in the agricultural sector are female. ${ }^{5}$ From this perspective, it is interesting to examine women's roles in rangeland management. Specifically, we compared socioeconomic outcomes of female-led and male-led herder households and community groups.

\section{Rangeland Management in Mongolia}

About a third of Mongolia's population depends on livestock husbandry for its livelihoods, and livestock husbandry accounts for $75 \%$ of Mongolia's total agricultural production. This demonstrates the important role that pastoralism has in the country's economy and the subsistence of the rural population. However, rangeland ecological condi- tions are widely perceived to be degrading ${ }^{\mathrm{i}}$ with the doubled increase of both livestock number and herding households since $1990 .{ }^{5}$ This, in turn, has a negative effect on the wellbeing of pastoral communities. From the mid-1990s, the government, together with donor organizations, has made substantial efforts to tackle rangeland degradation and rural poverty in Mongolia. One such effort is facilitation of community-based rangeland management groups among the herders. This has eventually led to the development of two forms of pastoral groups in rural Mongolia. The first are herders who retain their traditional ways of herding, albeit considerably influenced by newly introduced market forces. The second are herders who, with the help of donor-sponsored projects, have formally organized into communitybased rangeland management groups to meet the challenges of the market economy and resource management more effectively. As of 2007, there were about 2,000 such formal community-based herder organizations in Mongolia. These organizations have been the subject of research examining their effectiveness at improving rangeland conditions. Recent studies suggest that formally organized community groups have more positive outcomes than traditional herder communities. For instance, Leisher et al. ${ }^{8}$ found $11 \%$ more biomass on average in the pastures managed by formally organized groups compared with the traditional neighborhoods in the period of 2000 to 2009 . The same study confirmed $12 \%$ greater income being earned by the members of the organized groups. Similar findings have triggered further scientific investigation to identify what factors make these groups more effective. ${ }^{8,9}$ Research has revealed several contributing factors, such as strong trust-building, networking, knowledge exchange, and information sharing among group members. All of these together lead to improved collective action ${ }^{\text {ii }}$ for the benefit of the whole community and its natural resource assets..$^{9,11,12}$ In many cultural settings, gender has been one of the factors that have facilitated collective action. Women's participation increases the diversity of views and helps to address specific needs of different community members, which, in turn, strengthens collective decision-making and governance processes within the community organizations. ${ }^{13,14}$ In this study, we explored the relationship between gender and rangeland management by Mongolian herder communities. In particular, we wanted to answer the research question "Do female-led and male-led herder households and community groups differ in terms of socioeconomic outcomes?"

'According to some studies ${ }^{6,7}$ and herders' observations, degradation in Mongolian rangeland occurs in the forms of increasing soil erosion, blowing sand, soil alkalization, and unpalatable species, as well as decreasing biomass production, especially, in areas close to towns and water points.

"The concept of collective action is used in this study following the Ostrom $^{10}$ institutional design principles, including presence of agreement of local users for resource improvement, membership to such agreement, and joint actions to achieve the common goal. 


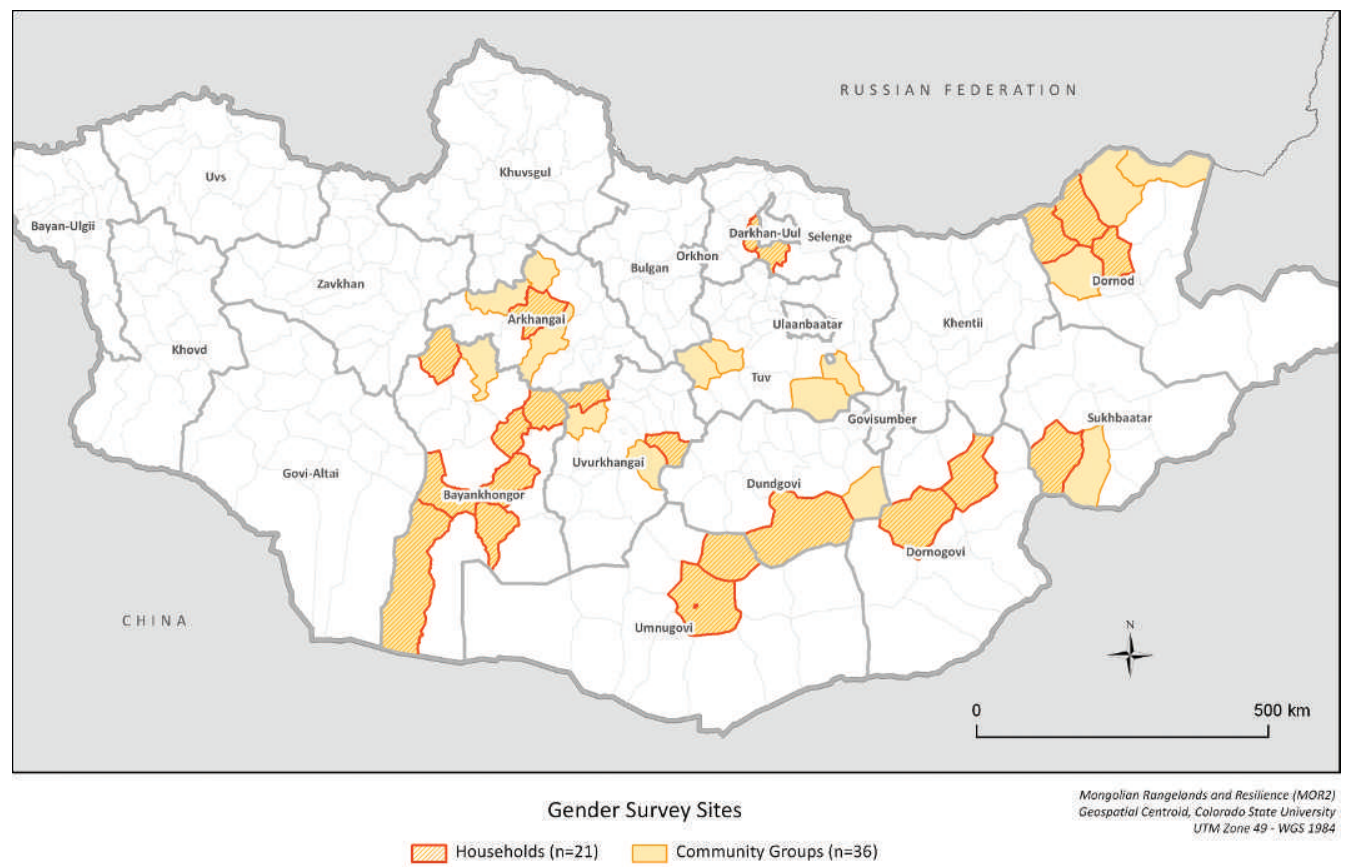

Figure 2. Sites for study of gender effects on rangeland management: sampled provinces and counties in Mongolia.

\section{Research Site and Study Objectives}

We studied the effects of gender at two different levels of society: the household and community groups comprising households (see Fig. 2). Our study included 36 counties or soums, iii from which we sampled 140 pastoral community groups with 21 (15\%) having women leaders. At the household level, we collected data from 706 households across all 36 soums. However, from this full sample, we subsampled 84 households because there were only 37 female-led households. We randomly sampled 47 matching male-led households in the same soums where the female-led families were surveyed (Table 1). We used this approach to keep other variables similar-including geographic location, resource condition, climate, and economic factors - all of which may influence outcomes of rangeland management.

At the household level, we wanted to know if there were differences between female-led and male-led households in terms of socioeconomic outcomes. Specifically, we focused on vulnerability to livestock losses, access to food, livelihood status, and participation in knowledge exchange and collective action. We expected that female-led households would be disadvantaged with higher vulnerability and lower socioeconomic status (livelihood) compared with the male-led households. Our indicator of vulnerability was percentage loss of livestock in a recent severe winter (dzud, in Mongolian) of 2009-2010. Access to food was measured by per capita household expenditures on basic food items. Livelihood was measured based on number of livestock per capita and own-

iii Soum is a rural administrative unit in Mongolia with a human population ranging from 3,000 to 10,000 .
Table 1. Sampling at household and community group levels for study of gender effects of rangeland management among Mongolian pastoral herders

\begin{tabular}{|l|l|l|l|l|}
\hline $\begin{array}{c}\text { Unit of } \\
\text { analysis }\end{array}$ & \multicolumn{2}{|c|}{$\begin{array}{c}\text { Household } \\
(\mathbf{N}=\mathbf{8 4})\end{array}$} & \multicolumn{2}{|c|}{$\begin{array}{c}\text { Community } \\
\text { group } \\
(\mathbf{N = 1 4 0 )}\end{array}$} \\
\cline { 2 - 5 } & No. & $\%$ & No. & $\%$ \\
\hline Male-led & 47 & 56 & 119 & 85 \\
\hline Female-led & 37 & 44 & 21 & 15 \\
\hline Total & 84 & 100 & 140 & 100 \\
\hline
\end{tabular}

ership of assets essential to sustain the household economy. To assess knowledge exchange and participation in collective action for range management, we used herders' responses to survey questions about their information sources, social networks for information exchange, and participation in range management activities.

At the community group level, we aimed to explore differences between female-led and male-led groups in the level of trust ${ }^{\text {tv }}$ in leaders and fellow herders, leader legitimacy

iv Trust was measured using five questions about trustworthiness of local leaders, and other community members with three-scale responses of disagree/neutral/agree. 
Table 2. Comparison of social indicators between male-led and female-led households of Mongolian pastoral communities

\begin{tabular}{|c|c|c|c|}
\hline Variables measured & Unit of calculation & $\begin{array}{l}\text { Mean for male-led } \\
\text { households }\end{array}$ & $\begin{array}{l}\text { Mean for female-led } \\
\text { households }\end{array}$ \\
\hline \multicolumn{4}{|l|}{ Vulnerability } \\
\hline $\begin{array}{l}\text { Dzud loss, proportion of } \\
\text { total herd }\end{array}$ & $\%$ & 10.0 & 6.5 \\
\hline $\begin{array}{l}\text { Food expenditure, annual } \\
\text { per capita }\end{array}$ & US\$ & $214.9^{*}$ & $330.1^{*}$ \\
\hline \multicolumn{4}{|l|}{ Livelihoods } \\
\hline Household assets & Count of basic assets & $6.8^{*}$ & $5.3^{*}$ \\
\hline Livestock per capita & No. in sheep unit & 160.3 & 133.1 \\
\hline Knowledge exchange & Sum of responsest & $8.0^{*}$ & $6.8^{*}$ \\
\hline Collective action & Sum of responsesł & $13.7^{\star}$ & $11.6^{*}$ \\
\hline \multicolumn{4}{|c|}{$\begin{array}{l}\text { * Statistically significant difference at } P<0.10 \text {. } \\
\text { † Sum of positive responses to } 16 \text { survey questions. } \\
\text { \#Index variable that summed four different variables, including } 1 \text { ) membership in various associations and local clubs, 2) } \\
\text { proactiveness for raising rangeland issues to local decision-makers and community members, 3) traditional range management } \\
\text { practices for past } 5 \text { years, and } 4 \text { ) innovative range management activities for the past year. }\end{array}$} \\
\hline
\end{tabular}

and leadership quality as perceived by group members, and the presence of grazing regulations. Based on the history of Mongolian women's leadership qualities, and the proactive attitudes we observed in our experience working with these women, we anticipated that female-led community groups would score higher on these indicators of leadership, trust, and effectiveness of enforcement than male-led groups. We used analysis of variance (ANOVA) to test our hypotheses. Considering small sample sizes, we set $P$ value at 0.10 for the statistical tests.

\section{Gender Differences Across Households and Community Groups}

In terms of descriptive statistics, we found male-led households were larger than female-led households, with $64 \%$ of the former having four to seven members, compared with $46 \%$ of the latter. Nearly $22 \%$ of female-led households were led by widowed or divorced women, whereas single male-led households were rare (4.3\%). Another contrast we observed was that $34 \%$ of male heads of household were younger than 35 years (compared with $5.4 \%$ of female heads), and $19 \%$ of female heads were older than 60 years (compared with 8.5\% of male heads). A closer examination showed that singleperson family heads were prevailingly older women. Aligned with national statistics on women's education in Mongolia, $19 \%$ of female heads had technical and tertiary level education in contrast to only $2 \%$ of male heads.

Female-led households had significantly fewer durable assets, such as a truck or motorcycle, television, or cell phone and had limited access to knowledge exchange and information sharing, compared with male-led households (Table 2). Significantly fewer female-led households participated in collective action compared with male-led households. However, female-led households spent significantly more on food compared with male-led households. This suggests that women may prioritize food expenditures for the benefit of children, potentially leading to better nutritional status for household members, which was the case for African women. ${ }^{15}$ On the other hand, in the face of overall income deficit, we speculate that this spending pattern may lead to greater debt.

In contrast to our expectations, we found few differences between female-led and male-led community groups. Across the four variables of leader legitimacy, leadership quality, trust among members, and adherence to grazing rules, only the trust level was found to be statistically different between the two groups. Female-led groups had significantly higher trust scores (mean 3.13) in comparison to male-led community groups (mean 2.78). 


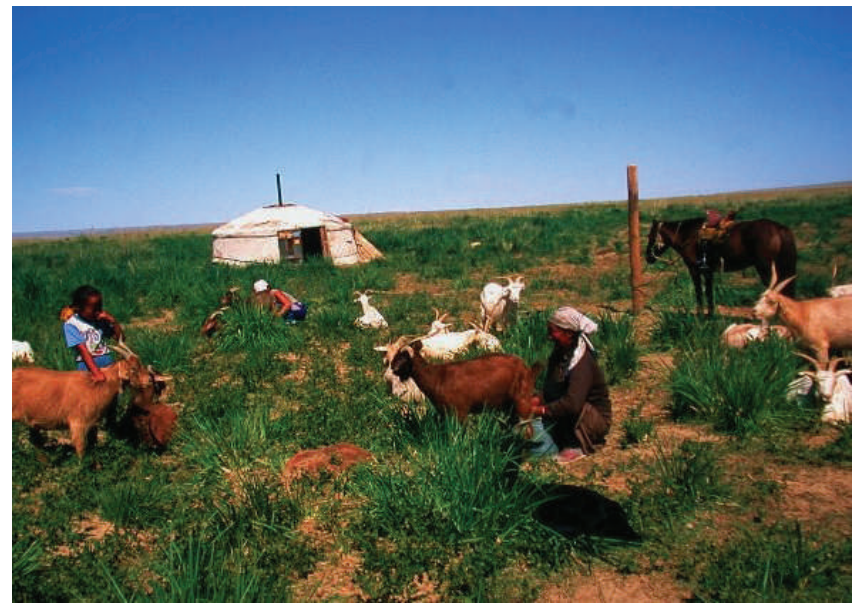

Figure 3. Mongolian woman milking goats. Photo courtesy of Sabine M. Schmidt.

Overall, this analysis partially confirms our initial prediction that female-led households may be more vulnerable. Although male-led and female-led households did not significantly differ in total livestock holdings or percentage of losses in the most recent winter disaster, female-led households had fewer assets, on average, and access to information was more restricted. In addition, female-led households participate less in local initiatives and, therefore, may benefit less from community collaborations. At the community level, our hypotheses were not supported with a lack of statistical difference between female-led groups and male-led groups, except for higher levels of reported trust in groups led by women (see Fig. 3).

\section{Does Gender Matter for Range Management in Mongolia?}

Based on our results, it seems that gender does matter for achieving positive outcomes of rangeland management in Mongolia. At the household level, many male household heads were younger than 35 years, an age when they still benefit from the advice and guidance of senior herders. Female heads had higher education levels and were older and more experienced, which suggests greater potential for contributing to local decision-making and collective-action activities. When experienced senior women or those female heads with higher education stay at home and do not participate in collective efforts, the entire community can lose the opportunity to learn from their experience and knowledge. On the other hand, because female heads of household are more vulnerable in the face of shocks, such as sickness, death of family member, natural disaster, or price fluctuations, there should be a specific mechanism to protect them from such hazards and prevent the total loss of livelihoods, health, and even selfidentity.

The analysis of the community groups illustrated similar leaderships of both male-led and female-led organizations. Pastoral women demonstrate the same degree of key mana-

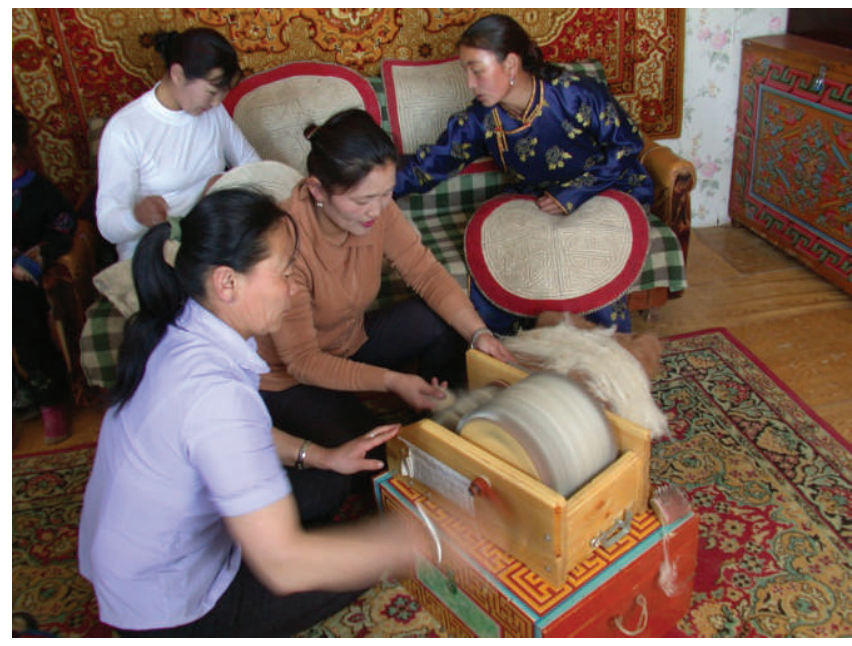

Figure 4. Herder women are engaged in wool processing and felting carpets that provide an important source of income to rural households. Photo courtesy of Sabine M. Schmidt.

gerial qualities as men do in organizing their livelihoods and resources. Moreover, female leaders built greater trust among their group members. Trust is a pivotal factor for developing stronger ties among herders, reducing transaction costs associated with collective action and strengthening a group's social bonds and cooperation. ${ }^{16}$ Theory suggests that strong social capital that incorporates trust, networking, and norms of reciprocity among group members may lead to improved rangeland management and, ultimately, to better natural resource conditions. Empowering nomadic women to take on community leadership roles may contribute to more successful pastoral communities and sustainable rangelands (see Fig. 4).

\section{Empowering Women for Mongolian Rangeland Management}

Following the legacy of their impressive female ancestors, Mongolian women pastoralists demonstrate leadership qualities and reputations at least equal to that of their male counterparts. Because women display superior abilities in building trust among their group members, they should be encouraged to take on more leadership and management roles. A possible constraint for this ambition, however, is whether women can cope with multiple burdens that include serving as caregivers, tending to household chores, and becoming community leaders (see Radel and Coppock as well as Ganguli and Launchbaugh, this issue).

In our sample, the ratio of male-led to female-led community groups was 140:21, suggesting ample room for women to expand their leadership roles. The current ratio echoes the overall weak participation of Mongolian women in elected and appointed political positions throughout contemporary Mongolian society. Perhaps, if more women took on local leadership positions at the community level, it might eventually lead to greater acceptance and confidence in women as leaders in other levels of political organization (see Fig. 5). 


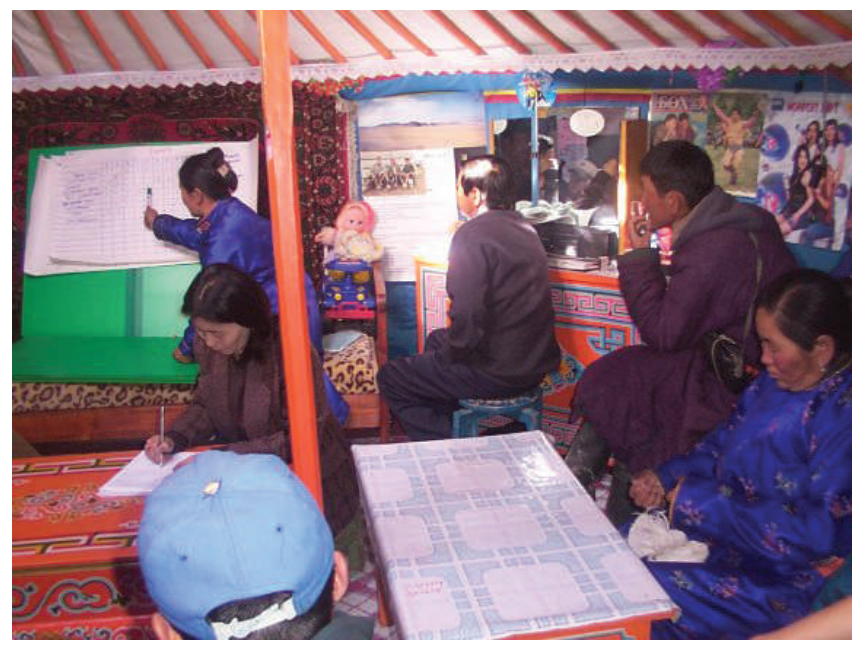

Figure 5. Community leader woman is explaining their group plan made using a participatory seasonal-calendar method. Photo courtesy of Keith Swenson.

Our results suggest the need for a differentiated policy approach toward empowering pastoral women in Mongolia. Policies should focus on 1) reducing vulnerability of femaleled households by enabling them to obtain greater access to information, learning from others, sharing their experiences, and contributing to community actions; and 2) encouraging and supporting women as leaders of community groups seeking to reduce rangeland degradation and alleviate poverty within nomadic communities. However, such policy should be general enough to provide a necessary legal framework and to guide local initiatives for achieving those objectives in their own ways. For instance, such policies might encourage community-based rangeland management groups to include local senior females as their members and have at least one to two women in their decision-making structures. Equally, there can be incentives for community groups that included vulnerable households into their social safety network and improved their well-being by collective support. Similar practices were demonstrated by some of the community-based groups in the southern Mongolia, but, in the absence of an overarching policy, that has not been widely replicated. The policy should also guide the local government plans to mainstream their efforts for improved rangeland management and alleviation of rural poverty with those of organized community groups. It has been shown that, when empowered, "women can improve multiple aspects of household welfare." ${ }^{17}$ Gender-mainstreamed capacity building for the community-based groups will enable well-educated pastoral women to become change agents for more effective range management in Mongolia. Adoption of the suggested policies might benefit not only promotion of women roles in rangeland management toward positive outcomes but also encourage bottom-up initiatives that might reduce burden of the government for resource management and social welfare.

\section{Acknowledgments}

We would like to thank pastoral community members of 36 soums in Mongolia for sharing their information with us. We also acknowledge members of the social team of Mongolian Rangelands and Resilience project, including researchers from the Center for Nomadic Pastoralism Studies, Nutag Partner, and the Mongolian Institute of Geo-Ecology. Special thanks to Sophia Linn and Arren Mendezona Allegretti, Colorado State University for mapmaking. The SRM International Affairs Committee provided travel support for Ulambayar to participate in the 2013 SRM symposium "Women as Change Agents on the World's Rangelands," in Oklahoma City, Oklahoma. This article is based on the presentation given there.

\section{References}

1. Weatherford, J. M. 2004. Genghis Khan and the making of the modern world. New York, NY, USA: Crown.

2. World BAnk. 2013. World databank: world development indicators. Available at: http://databank.worldbank.org. Accessed 22 April 2013.

3. Weatherford, J. M. 2010. The secret history of the Mongol queens: how the daughters of Genghis Khan rescued his empire. New York, NY, USA: Crown Publishers. xiv p.

4. Hausmann, R., L. D. Tyson, S. Zahidi [eds.]. 2012. The global gender gap report. Geneva, Switzerland: World Economic Forum.

5. National Statistical Office of Mongolia. 2012. Mongolian Statistical Yearbook 2012. Ulaanbaatar, Mongolia: National Statistical Office. 460 p.

6. Yamamura, N., N. Fujita, and A. Maekawa. 2013. The Mongolian ecosystem network: environmental issues under climate and social changes. Tokyo, Japan: Springer.

7. Liu, Y. Y., J. P. Evans, M. F. McCabe, R. A. M. de Jeu, A. I. J. M. van Dijk, A. J. Dolman, I. Saizen. 2013. Changing climate and overgrazing are decimating Mongolian steppes. Plos One 8(2):e57599. doi:10.1371/journal.pone.0057599.

8. Leisher, C., S. Hess, T. M. Boucher, P. van Beukering, AND M. SANJAYAN. 2012. Measuring the impacts of communitybased grasslands management in Mongolia's Gobi. PLoS One 7(2):e30991. doi:10.1371/journal.pone.0030991.

9. Fernández-Giménez, M. E., B. Batkhishig, and B. BatBUYAN. 2012. Cross-boundary and cross-level dynamics increase vulnerability to severe winter disasters (dzud) in Mongolia. Global Environmental Change 22(4):836-851.

10. Ostrom, E. 2000. Collective action and the evolution of social norms. Journal of Economic Perspectives 14(3):137-158.

11. Baival, B. 2012. Community-based rangeland management and social-ecological resilience of rural Mongolian communities [thesis]. Ft. Collins, CO: Colorado State University. 263 p. Available at: http://hdl.handle.net/10217/67403. Accessed 23 April 2013.

12. Fernández-Giménez, M. E. 2012. Restoring community connections to the land: building resilience through community- 
based rangeland management in China and Mongolia. Cambridge, MA, USA: CABI.

13. Agarwal, B. 2000. Conceptualising environmental collective action: why gender matters. Cambridge Journal of Economics 24(3):283-310.

14. Cleaver, F. 2000. Analysing gender roles in community natural resource management-negotiation, lifecourses and social inclusion. Ids Bulletin-Institute of Development Studies 31(2):60-67.

15. Yunus, M. 1999. The Grameen Bank. Scientific American, 281(5):114-119.

16. Putnam, R. D. 2000. Bowling alone: the collapse and revival of American community. New York, NY, USA: Simon \& Schuster.

17. Coppock, D. L., S. Desta, S. Tezera, and G. Gebru. 2011. Capacity building helps pastoral women transform impoverished communities in Ethiopia. Science 334(6061):13941398.
Authors are Graduate Research Assistant, Dept of Forest and Rangeland Stewardship, Colorado State University, Fort Collins, CO 80523-1472, USA, tungaa@rams.colostate.edu (Ulambayar); and Professor, Dept of Forest and Rangeland Stewardship, Colorado State University, Fort Collins, CO 80523-1472, USA (Fernández-Giménez). This article is based on work supported by the National Science Foundation under CNH Program Grant BCS-1011 "Does community-based rangeland ecosystem management increase the resilience of coupled systems to climate change in Mongolia?" Any opinions, findings, and conclusions or recommendations expressed in this material are those of the authors and do not necessarily reflect the views of the National Science Foundation.

Rangelands 35(6):29-35

doi: 10.2111/RANGELANDS-D-13-00035.1

(C) 2013 The Society for Range Management 